\title{
In Vitro Production of Cormels in Gladiolus hybridus through Gamma Rays
}

\author{
Neha Dogra* and K.K. Dhatt \\ Department of Floriculture and Landscaping, Punjab Agricultural University, \\ Ludhiana-141004, Punjab, India \\ *Corresponding author
}

\begin{tabular}{|c|c|}
\hline & A B S T R A $\mathbf{C}$ \\
\hline & \multirow{10}{*}{$\begin{array}{l}\text { The present experiment was conducted to standardize the protocol for in vitro mutagenesis } \\
\text { of gladiolus hybridus varieties 'Punjab Glance' and 'Sylvia'. The nodal buds were } \\
\text { irradiated with different doses of gamma rays }\left(\mathrm{Co}^{60}\right) 0,5,8,10 \text { and } 12 \mathrm{~Gy} \text {. Irradiated } \\
\text { explants were then cultured aseptically on MS basal medium supplemented with } 5 \mathrm{mg} / 1 \\
\text { (BAP) }+2 \mathrm{mg} / \mathrm{l} \text { (IBA) and agar-agar to induce shoot and root proliferation. Explants treated } \\
\text { at higher doses ( } 10 \text { and } 12 \mathrm{~Gy}) \text { showed deleterious effects of ionizing radiation. } \\
\text { Morphological abnormalities in terms of stunted growth were observed at } 10 \text { and } 12 \mathrm{~Gy} \text { of } \\
\text { gamma rays. The minimum time taken to shoot and root }(14.07),(15.06) \text { formation, days } \\
\text { to cormel formation }(60.04 \text { days) at } 8 \mathrm{~Gy} \text {. Shoot length }(4.04 \mathrm{~cm}) \text {, number of shoots } \\
\text { (25.07), root length ( } 4.18 \mathrm{~cm}) \text {, number of roots per }(10.04) \text {. In vitro-raised mutant cormels } \\
\text { and non-irradiated (control) plants were transferred to plastic pots one month after } \\
\text { acclimatisation under laboratory conditions and examined for their morphological traits. } \\
\text { These mutated cormels were multiplied on a large-scale through micropropagation and } \\
\text { evaluated for their stability. This study developed a mutagenesis protocol that could be } \\
\text { used to develop novel colour mutants in gladiolus. }\end{array}$} \\
\hline & \\
\hline $\begin{array}{l}\text { Gladiolus, Nodal } \\
\text { bud, Multiple }\end{array}$ & \\
\hline & \\
\hline $\begin{array}{l}\text { and Survival per } \\
\text { cent. }\end{array}$ & \\
\hline Article Info & \\
\hline $\begin{array}{l}\text { Accepted: } \\
\text { 14 September } 2017\end{array}$ & \\
\hline Available Online: & \\
\hline & \\
\hline & \\
\hline
\end{tabular}

\section{Introduction}

Gladiolus (Gladiolus hybridus L.) is an important bulbous ornamental plant, is one of the most important and popular herbaceous cut flowers. The major gladiolus growing countries are Holland, Germany, and the United State of America. In India, the total area under gladiolus cultivation is around 1,270 hectares covering West Bengal, Sikkim, Himachal Pradesh, Jammu and Kashmir, Punjab, Karnataka, Tamil Nadu and Maharashtra. In Punjab, gladiolus is grown in an area of about 150 ha during September to April (NHB 2014). It is grown worldwide for cut flower trade and garden displays. It occupies a pristine place in the garden for its magnificent inflorescence, wide array of colours, and fascinating varieties of shapes and sizes (Singh et al., 2010). Gladiolus is propagated mainly through vegetative reproduction of corms and cormels. Although, seeds are an effective means of propagation in gladiolus but plants raised from seed may not produce true to type plants (Hussain et al., 2001). Moreover, it takes more time for blooming. However, the multiplication rate of corms and cormels is slow and the conventional methods are insufficient to meet the demand of planting material. However, one of the major constrains in commercial cultivation is non-availability of large 
quantity of propagules that transmit viral, fungal and bacterial diseases e.g. Fusarium corm rot, Botrytis blight, bacterial leaf rot etc, thus causing a heavy loss (Singh and Dohare 1994). A large corm produces one daughter corm and few cormels for its multiplication. Besides, most of the hybrid cultivars of gladiolus have a very slow rate of multiplication and it takes many years before the cultivar can be released. Gladioli production also declines due to incidence of Fusarium corm rot caused by Fusarium oxysporum f. gladioli, viral and some other diseases which cause to a great extent of commercial losses (Roy et al., 2006, Sinha and Roy 2002). To boost economical production, it is highly desirable to develop methods to increase rate of multiplication. Clonal propagation through tissue culture has been commercially exploited in a large number of plant species. (Holdgate, 1977; Hussey, 1977; Ziv, 1979; Logan and Zettler, 1985) also reported in gladiolus. In vitro cormel production from nodal buds and cormel tip has been achieved successfully (Arora et al., 1996). It has been also successfully tried from inflorescence stalks (Ziv et al., 1970), axillary buds of corm (Dantu and Bhojwani 1995) and nodal buds (Grewal et al., 1995).

Mutation breeding is an established method for crop improvement and has played a major role in the development of many new flower colour and shape mutants in ornamentals. Conventionally, in vegetatively propagated ornamentals, corms are treated with gamma rays before planting. In these treated plants, mutation appears as chimeras, which remains the main bottleneck in mutation breeding (Datta 2005). However, In vitro culture methods have facilitated the use of mutationassisted breeding techniques to improve both sexually and vegetatively propagated crops. In vitro mutagenesis is a powerful tool that can be exploited to increase genetic variability in an already economically important cultivar. Induced mutations have been used to generate a wide range of plants with improved resistance to abiotic and biotic stresses (Jain 2005, Sudhir et al., 2006). Among the tools available to induce in vitro mutations, physical or chemical mutagens have high potential for horticultural crops due to their ease of application and high efficiency. Among the physical mutagens, Xrays are the most convenient and easiest to apply and have led to altered flower colours. Mutagenesis to induce novel mutants in rose and chrysanthemum has been reported previously (Datta 1995; Arnold et al., 1998; Kim et al., 2006). The aim of this study was to standardize an efficient protocol for in vitro mutagenesis that could be used further multiplication of breeding material or for commercial purpose.

\section{Materials and Methods}

The experiment was carried out at Tissue Culture Laboratory of Department of Floriculture and Landscaping, PAU Ludhiana in 2015-16. The nodal buds of varieties 'Punjab Glance' and 'Sylvia' was used as source of material in this study. The conical flasks containing 2-3 bud clumps of uniform size $(2 \mathrm{~cm})$ were irradiated with different doses of gamma rays $(0,5,8,10$ and 12 Gy) using three replication per treatment at Department of Fruit Science, Punjab Agricultural University, Ludhiana, using gamma rays Low Dose Irradiator 2000 ANSI$\mathrm{N}$ 433.1. The buds were cultured on the medium were transferred to flasks containing fresh Murashige and Skoog (1962) medium supplemented with BAP 5mg/l + IBA 2mg/l to develop roots then cormels. Explant cultures were maintained at $25^{\circ} \pm 1^{\circ} \mathrm{C}$ under cool-white fluorescent lamps with a $16 \mathrm{~h}$ photoperiod. Each treatment comprised of 5 flasks containing 2-3 bud clumps each replicated thrice. Untreated bud clumps were retained as control. To determine the shoot and root formation buds clumps that 
multiplied on the above medium were separated and individual micro- bud clumps were transferred on to hormone free MS medium for shoot elongation. The buds clumps grew into $4-5 \mathrm{~cm}$ long shoots on this medium after incubation of 4 weeks. Elongated shoots were transferred to conical glass flasks on the medium containing $2 \mathrm{mg} / \mathrm{l}$ of IBA. The roots were formed after 4 weeks. With the objective to evaluate the optimum culture medium for in vitro cormel production, the half strength MS medium (1/2 MS) containing IBA $(2 \mathrm{mg} / \mathrm{l})$ and sucrose 3 and 6 percent was used. The cormel formation started after about 30-60 days. Young small cormels of gladiolus were taken out of the glass jars and washed with distilled water and planted in small pots containing media (sand + perlite + vermiculite). The observations were recorded on in vitro bud clumps, days to shoot formation, shoot length, number of shoots, quality of shoots, root length, days to root formation, number of roots, time taken for cormel formation, number of cormels and size of cormels. Progeny of irradiated and untreated plant-lets were run through hardening process and transferred to the field. Data on field survival (\%), leaf length, leaf width, number of cormels and corm size were recorded. The experiment was conducted as per treatments in Factorial Completely Randomized Design (FCRD). The statistical analysis was performed using SAS software and treatment means were compared using Duncan Multiple Range Test (DMRT) at 5\% level of significance (Duncan 1955).

\section{Results and Discussion}

\section{Radiation effect on shoot formation}

The results pertaining to survival of tissue cultured bud clumps after irradiation are presented in Table 1. Gamma irradiation dose resulted in increased plant mortality. Significant reductions in shoot proliferation in 'Punjab Glance' and 'Sylvia' was studied in terms of days to shoot initiation, shoot length, number of shoots per callus and quality of shoots with increasing gamma ray dose. The results indicated that higher dose of gamma irradiation resulted in increased plant mortality. The time required for shoot formation was increased with the increased doses of gamma rays. The shoot clumps of variety 'Punjab Glance' treated at 8 Gy took 14.07 days for initiation of shoots from callus. The other doses of gamma rays i.e. 10 and 12 Gy took more time for shoot formation and gave significant result in respect of days required for shoot initiation from callus in gladiolus. Maximum days 24.66 days for shoot formation were taken by $12 \mathrm{~Gy}$. The shoot clumps of variety 'Sylvia' treated at 8 Gy took 14.48 days for initiation of shoots from callus. The other doses of gamma rays i.e. 10 and 12 Gy took more time for shoot formation and gave significant result in respect of time required for shoot initiation from callus in gladiolus. The maximum time of 25.00 days for shoot formation were taken by 'Sylvia' variety treated with 12 Gy. This might be due to varietal differences.

Maximum shoot length $(6.31 \mathrm{~cm})$ was found at $8 \mathrm{~Gy}$. Shoot length was decreased to 4.04 $\mathrm{cm}$ at 12 Gy in 'Punjab Glance'. In 'Sylvia 'maximum shoot length was found at $8 \mathrm{~Gy}$ $(6.07 \mathrm{~cm})$ and shoot length decreased to 3.66 $\mathrm{cm}$ at higher dose of $12 \mathrm{~Gy}$. The maximum number of shoots per explants (50.19) was formed after three sub-cultures at 8 Gy followed by 48.11 at $5 \mathrm{~Gy}$, whereas the minimum number of shoots (25.07) was observed at 12 Gy dose in 'Punjab Glance'. In 'Sylvia' maximum number of shoots (50.07) per explants were observed at 8 Gy followed by 48.04 at $5 \mathrm{~Gy}$ dose. The minimum number of shoots (24.55) was reported at $12 \mathrm{G}$ in 'Sylvia'. The better quality of shoots was obtained at 5 and 8 Gy (dark green, erect and thick) in both varieties. Poorest quality of shoots was found at higher dose of gamma rays at 12 Gy (lanky, thin and light green). 
The synergistic effects of cytokinins with auxins are responsible for the production of high quality shoots. The inhibitory effect of higher doses of gamma irradiation on shoot number and shoot elongation might be due to disturbances in physiological and biochemical processes related to the action of gibberellic acid, which normally stimulates cell division and cell elongation. Reductions in shoot length might also be due to radiation killing meristematic cells, or damaged cells producing fewer progeny cells. Similar results have been reported by several workers (Datta and Banerji, 1995) in chrysanthemum. Inhibitory effect of gamma rays on number of shoots had also been reported by (Kasumi et al., 2001) in gladiolus.

\section{Radiation effect on vegetative growth}

The incidence of abnormal leaf shapes, leaf lamina, albinism, leaves with less chlorophyll and variegated leaves with stunted growth increased at higher doses of gamma rays in cultures of nodal explants treated at $12 \mathrm{~Gy}$ was reported in 'Punjab Glance' (7.91\%) and in 'Sylvia'(8.04 \%). The development of abnormal leaves in gamma ray-treated plants was probably due to physiological disturbances or chromosomal aberrations. Colour variations in irradiated leaves might be due to reduced levels of substrates affecting biochemical pathways. Abnormalities in the colour, form, and texture of leaves following irradiation have been reported in rose, carnation, chrysanthemum and other ornamental crops by several workers (Singh et al., 1999; Kumar 2002, Kumari et al., 2013). Kapadiya et al., (2014) also reported that vegetative abnormalities were higher at gamma rays.

\section{Radiation effect on rooting}

The days taken for root formation, root length and number of roots produced per callus were presented in Table 2. The time required for root formation increased with the increased doses of gamma rays. Variety 'Punjab Glance' took 15.06 days was for initiation of roots from callus treated at $8 \mathrm{~Gy}$. All the other doses of gamma rays took more time for root formation and gave significant result in respect of time required for root initiation from callus in gladiolus. The maximum time 24.95 days was taken at $12 \mathrm{~Gy}$. As per the results of Table 2 variety 'Sylvia' took minimum time (15.14 days) when treated at 8 Gy for initiation of roots from callus. All the other doses of gamma rays took more time for root formation and gave significant result in respect of days required for root initiation from callus in gladiolus. Maximum time 25.00 days were taken at $12 \mathrm{~Gy}$. Maximum root length was found at $8 \mathrm{~Gy}(8.10 \mathrm{~cm})$ and it was decreased to $4.18 \mathrm{~cm}$ at $12 \mathrm{~Gy}$ in 'Punjab Glance'.

However in variety 'Sylvia 'maximum root length was found at $8 \mathrm{~Gy}(7.93 \mathrm{~cm})$ and decrease as the doses of gamma rays were increased and reported $4.00 \mathrm{~cm}$ at $12 \mathrm{~Gy}$ treatment. The maximum number of roots per explant (30.04) was found at 8 Gy followed by (29.04) 5 Gy dose, whereas the minimum number of roots (10.04) was observed at 12 Gy in 'Punjab Glance'.

The maximum number of roots per explant (28.59) was found at 8 Gy followed by (26.04) 5 Gy dose, whereas the minimum number of roots (9.04) was observed at $12 \mathrm{~Gy}$ dose in 'Sylvia'. Lower doses of gamma rays took less time for root formation, more root length and more numbers of roots. This could be due to perturbations of the endogenous hormone balance, and the action of phytohormones synthesised and transported from the shoot tip to their site of action, or by the exogenous supply of synthetic auxins. The inhibition of rooting following higher doses of gamma irradiation supports the results obtained by others (Gordon, 1957; Singh et al., 1999). 

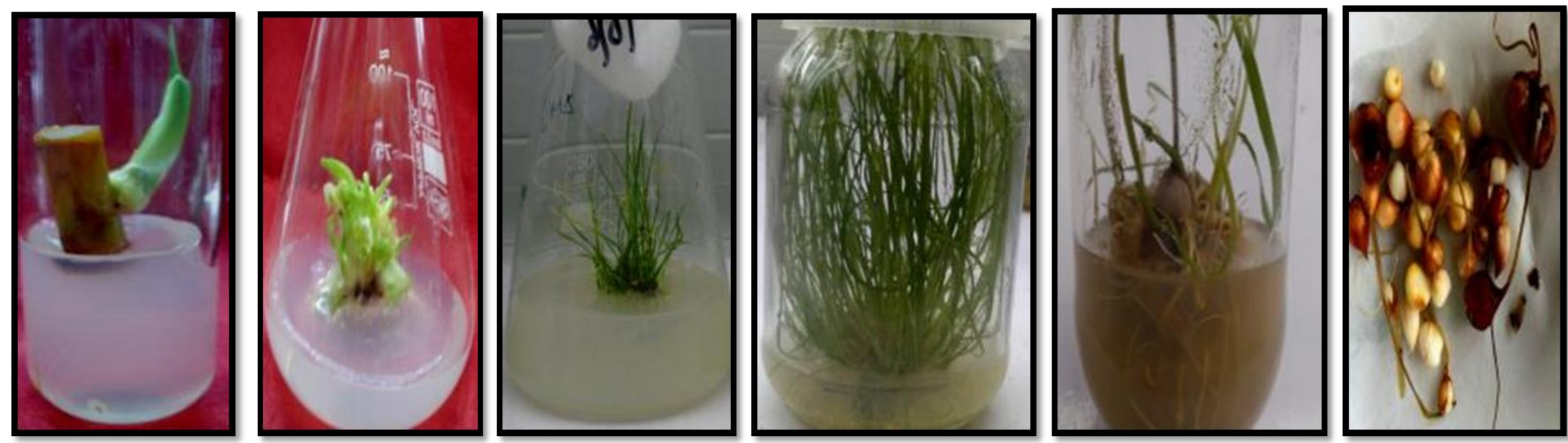

Best in vitro Cormel multiplication on MSmedium supplemented with $2 \mathrm{mg} / \mathrm{l}$ with elevated sucrose (6 $\%$ ) at 8 Gy

Best shoot elongation and growth in hormone free media in (8 Gy)

Callus initiation ( $8 \mathrm{~Gy})$

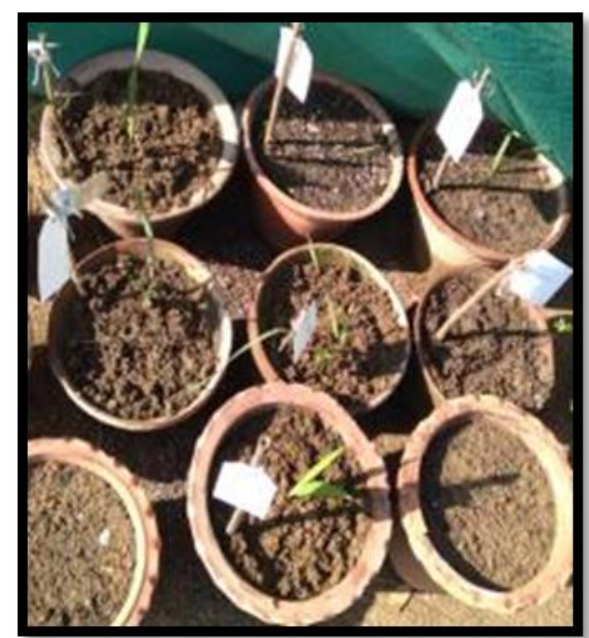

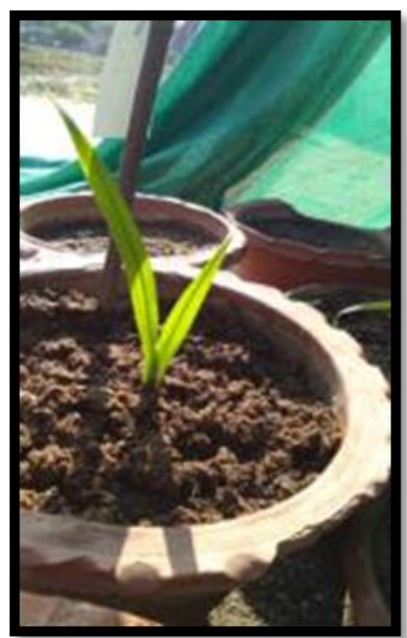
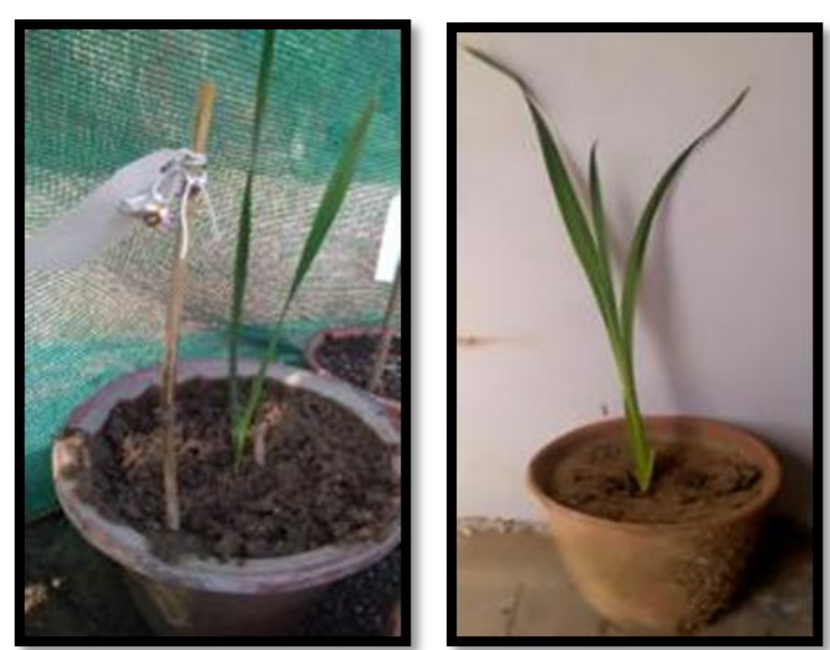

Regenerated plantlets having well root system are transferred on hardening media containing

a) Garden Soil+ Sand+Perlite+ Vermiculite

h) c) d) Plantlets transferred on Garden soil + Sand 
Table.1 Effect of different doses of gamma rays on survival (\%), days to shoot formation, shoot length, number of shoots per callus, leaf abnormalities and quality of shoots in gladiolus varieties 'Punjab Glance' and 'Sylvia'

\begin{tabular}{|c|c|c|c|c|c|c|c|c|c|c|}
\hline \multirow{2}{*}{$\begin{array}{l}\text { Doses of } \\
\text { gamma } \\
\text { rays }(\mathrm{Gy})\end{array}$} & \multicolumn{5}{|c|}{ Punjab Glance } & \multicolumn{5}{|c|}{ Sylvia } \\
\hline & $\begin{array}{c}\text { Days to } \\
\text { shoot } \\
\text { formation }\end{array}$ & $\begin{array}{c}\text { Shoot } \\
\text { length } \\
\text { (cm) }\end{array}$ & $\begin{array}{c}\text { Number of } \\
\text { shoots/ } \\
\text { callus }\end{array}$ & $\begin{array}{c}\text { Leaf } \\
\text { abnormalities } \\
(\%)\end{array}$ & $\begin{array}{l}\text { Quality of } \\
\text { shoots }\end{array}$ & $\begin{array}{c}\text { Days to } \\
\text { shoot } \\
\text { formation }\end{array}$ & $\begin{array}{c}\text { Shoot } \\
\text { length }(\mathrm{cm})\end{array}$ & $\begin{array}{c}\text { Number of } \\
\text { shoots/ callus }\end{array}$ & $\begin{array}{c}\text { Leaf } \\
\text { abnormalities } \\
(\%)\end{array}$ & Quality of shoots \\
\hline O (control) & $19.66^{e}$ & $5.15^{c}$ & $44.74^{\mathrm{c}}$ & $\begin{array}{c}0.00 \\
(1.00)^{\mathrm{e}}\end{array}$ & $\begin{array}{l}\text { Green, thin and } \\
\text { lanky }\end{array}$ & $19.85^{c}$ & $5.04^{\mathrm{c}}$ & $44.07^{\mathrm{c}}$ & $\begin{array}{c}0.00 \\
(1.00)^{\mathrm{e}}\end{array}$ & $\begin{array}{l}\text { Green, thin and } \\
\text { lanky }\end{array}$ \\
\hline 5 & $14.33^{\mathrm{c}}$ & $6.07^{\mathrm{a}}$ & $48.11^{b}$ & $\begin{array}{l}40.07 \\
(6.40)^{\mathrm{c}}\end{array}$ & $\begin{array}{l}\text { Dark green, } \\
\text { erect thick }\end{array}$ & $14.92^{d}$ & $6.00^{b}$ & $48.04^{b}$ & $\begin{array}{c}41.33 \\
(6.50)^{c}\end{array}$ & $\begin{array}{l}\text { Dark green, erect } \\
\text { thick }\end{array}$ \\
\hline 8 & $14.07^{d}$ & $6.31^{b}$ & $50.19^{a}$ & $\begin{array}{c}34.66 \\
(5.96)^{d}\end{array}$ & $\begin{array}{l}\text { Dark green, } \\
\text { erect thick }\end{array}$ & $14.48^{\mathrm{e}}$ & $6.07^{\mathrm{a}}$ & $50.07^{\mathrm{a}}$ & $\begin{array}{c}36.66 \\
(6.13)^{d}\end{array}$ & $\begin{array}{l}\text { Dark green, erect } \\
\text { thick }\end{array}$ \\
\hline 10 & $21.04^{b}$ & $4.17^{\mathrm{d}}$ & $34.07^{d}$ & $\begin{array}{c}55.11 \\
(7.49)^{b}\end{array}$ & $\begin{array}{c}\text { Lanky, thin and } \\
\text { light green }\end{array}$ & $21.37^{b}$ & $4.06^{\mathrm{d}}$ & $33.99^{d}$ & $\begin{array}{c}55.33 \\
(7.50)^{\mathbf{b}} \\
\end{array}$ & $\begin{array}{l}\text { Lanky, thin and } \\
\text { light green }\end{array}$ \\
\hline 12 & $24.66^{\mathrm{a}}$ & $4.04^{\mathrm{e}}$ & $25.07^{\mathrm{e}}$ & $\begin{array}{l}61.66 \\
(7.91)^{\mathrm{a}}\end{array}$ & $\begin{array}{c}\text { Lanky, thin and } \\
\text { light green }\end{array}$ & $25.00^{\mathrm{a}}$ & $3.66^{\mathrm{e}}$ & $24.55^{\mathrm{e}}$ & $\begin{array}{c}63.66 \\
(8.04)^{\mathrm{a}}\end{array}$ & $\begin{array}{l}\text { Lanky, thin and } \\
\text { light green }\end{array}$ \\
\hline Mean & 18.75 & 5.14 & 40.43 & $\begin{array}{c}38.30 \\
(28.76) \\
\end{array}$ & NS & 19.12 & 4.96 & 39.16 & $\begin{array}{c}49.24 \\
(29.17) \\
\end{array}$ & NS \\
\hline LSD $^{(p=0.05)}$ & $\mathbf{0 . 8 3}$ & 0.19 & 0.57 & 0.34 & & 0.68 & 0.49 & 0.46 & 0.26 & \\
\hline
\end{tabular}

Table.4 Influence of gamma irradiation on field survival and growth of plantlets of gladiolus varieties 'Punjab Glance' and 'Sylvia'

\begin{tabular}{|c|c|c|c|c|c|c|c|c|c|c|}
\hline \multirow{2}{*}{$\begin{array}{c}\text { Doses of } \\
\text { gamma } \\
\text { rays }(G y)\end{array}$} & \multicolumn{5}{|c|}{ Punjab Glance } & \multicolumn{5}{|c|}{ Sylvia } \\
\hline & $\begin{array}{c}\text { Sprouting } \\
(\%)\end{array}$ & $\begin{array}{c}\text { Number of } \\
\text { cormels per } \\
\text { plant }\end{array}$ & $\begin{array}{c}\text { Corm } \\
\text { size }(\mathrm{cm})\end{array}$ & $\begin{array}{c}\text { Leaf } \\
\text { length } \\
(\mathrm{cm})\end{array}$ & $\begin{array}{c}\text { Leaf } \\
\text { width } \\
(\mathrm{cm})\end{array}$ & $\begin{array}{c}\text { Sproutin } \\
\text { g }(\%)\end{array}$ & $\begin{array}{c}\text { Number of } \\
\text { cormels } \\
\text { per plant }\end{array}$ & $\begin{array}{l}\text { Corm } \\
\text { size }\end{array}$ & $\begin{array}{l}\text { Leaf length } \\
(\mathrm{cm})\end{array}$ & $\begin{array}{c}\text { Leaf width } \\
\text { (cm) }\end{array}$ \\
\hline 0 (control) & $90.00^{\mathrm{a}}$ & $5.93^{\mathrm{a}}$ & $2.00^{b}$ & $31.00^{\mathrm{c}}$ & $1.13^{\mathrm{c}}$ & $87.00^{\mathrm{a}}$ & $5.66^{\mathrm{a}}$ & $1.90^{\mathrm{b}}$ & $30.33^{c}$ & $0.91^{\mathbf{c}}$ \\
\hline 5 & $86.33^{b}$ & $3.83^{b}$ & $2.20^{\mathrm{c}}$ & $33.20^{b}$ & $1.16^{b}$ & $83.33^{b}$ & $3.50^{b}$ & $2.00^{\mathrm{c}}$ & $32.33^{b}$ & $1.00^{b}$ \\
\hline 8 & $60.04^{c}$ & $3.20^{\mathrm{c}}$ & $2.67^{\mathrm{a}}$ & $42.33^{\mathrm{a}}$ & $1.83^{\mathrm{a}}$ & $58.00^{\mathrm{c}}$ & $3.00^{\mathrm{c}}$ & $2.50^{\mathrm{a}}$ & $41.33^{\mathrm{a}}$ & $1.68^{\mathrm{a}}$ \\
\hline 10 & $31.00^{d}$ & $1.85^{\mathrm{d}}$ & $1.85^{\mathrm{d}}$ & $25.56^{d}$ & $0.65^{d}$ & $29.66^{d}$ & $1.82^{d}$ & $1.72^{d}$ & $25.23^{d}$ & $0.59^{d}$ \\
\hline 12 & $22.00^{\mathrm{e}}$ & $1.00^{\mathrm{e}}$ & $1.00^{\mathrm{e}}$ & $16.16^{\mathrm{e}}$ & $0.48^{\mathrm{e}}$ & $20.33^{e}$ & $1.00^{\mathrm{e}}$ & $0.96^{\mathrm{e}}$ & $15.66^{e}$ & $0.45^{\mathrm{e}}$ \\
\hline Mean & 57.87 & 3.16 & 1.94 & 29.65 & 1.05 & 55.66 & 2.99 & 1.81 & 28.97 & 0.92 \\
\hline $\mathbf{L S D}^{(p=0.05)}$ & 3.43 & 1.22 & 0.39 & 3.01 & 0.41 & 4.61 & 1.04 & 0.28 & 3.32 & 0.39 \\
\hline
\end{tabular}


Table.2 Effect of different doses of gamma rays on days to root formation, root length, number of roots per callus in gladiolus varieties 'Punjab Glance' and 'Sylvia'

\begin{tabular}{|c|c|c|c|c|c|c|}
\hline \multirow{2}{*}{$\begin{array}{c}\text { Doses of } \\
\text { gamma } \\
\text { rays }(\mathbf{G y})\end{array}$} & \multicolumn{3}{|c|}{ Punjab Glance } & \multicolumn{3}{|c|}{ Sylvia } \\
\hline & $\begin{array}{l}\text { Days taken for } \\
\text { root formation }\end{array}$ & $\begin{array}{l}\text { Root length } \\
(\mathrm{cm})\end{array}$ & $\begin{array}{l}\text { Number of } \\
\text { roots per } \\
\text { callus }\end{array}$ & $\begin{array}{l}\text { Days taken for } \\
\text { root formation }\end{array}$ & $\begin{array}{l}\text { Root length } \\
(\mathrm{cm})\end{array}$ & $\begin{array}{l}\text { Number of } \\
\text { roots per } \\
\text { callus }\end{array}$ \\
\hline $\begin{array}{c}\mathbf{0} \\
\text { (control) }\end{array}$ & $18.85^{\mathrm{c}}$ & $5.55^{\mathrm{c}}$ & $25.07^{\mathrm{c}}$ & $20.10^{c}$ & $5.27^{\mathrm{c}}$ & $24.00^{\mathrm{c}}$ \\
\hline 5 & $18.00^{\mathrm{d}}$ & $7.04^{b}$ & $29.04^{b}$ & $18.14^{d}$ & $7.00^{b}$ & $26.04^{b}$ \\
\hline 8 & $15.06^{\mathrm{e}}$ & $8.10^{\mathrm{a}}$ & $30.04^{\mathrm{a}}$ & $15.14^{\mathrm{e}}$ & $7.93^{\mathrm{a}}$ & $28.59^{\mathrm{a}}$ \\
\hline 10 & $22.41^{b}$ & $5.00^{d}$ & $14.07^{d}$ & $22.74^{b}$ & $4.37^{\mathrm{d}}$ & $12.07^{d}$ \\
\hline 12 & $24.95^{\mathrm{a}}$ & $4.18^{\mathrm{e}}$ & $10.04^{\mathrm{e}}$ & $25.00^{\mathrm{a}}$ & $4.00^{\mathrm{e}}$ & $9.04^{\mathrm{e}}$ \\
\hline Mean & 19.85 & 5.97 & 21.65 & 20.25 & 5.82 & 18.93 \\
\hline$\underset{(p=0.05)}{\text { LSD }}$ & 0.63 & 0.41 & 0.18 & 0.56 & 0.47 & 0.45 \\
\hline
\end{tabular}

Table.3 Effect of different doses of gamma rays on time taken for cormel production, number of cormels per plant and size of cormels in gladiolus varieties 'Punjab Glance' and 'Sylvia'

\begin{tabular}{|c|c|c|c|c|c|c|}
\hline \multirow{2}{*}{$\begin{array}{c}\text { Doses of } \\
\text { gamma rays } \\
(\mathrm{Gy})\end{array}$} & \multicolumn{3}{|c|}{ Punjab Glance } & \multicolumn{3}{|c|}{ Sylvia } \\
\hline & $\begin{array}{l}\text { Time taken } \\
\text { for cormel } \\
\text { formation }\end{array}$ & $\begin{array}{c}\text { Number of } \\
\text { cormels }\end{array}$ & $\begin{array}{l}\text { Size of } \\
\text { cormels } \\
(\mathrm{mm})\end{array}$ & $\begin{array}{l}\text { Time taken } \\
\text { for cormel } \\
\text { formation }\end{array}$ & $\begin{array}{c}\text { Number of } \\
\text { cormels }\end{array}$ & $\begin{array}{c}\text { Size of } \\
\text { cormels }(\mathrm{mm})\end{array}$ \\
\hline 0 (control) & $75.04^{\mathrm{c}}$ & $19.04^{\mathrm{c}}$ & $11.00^{\mathrm{c}}$ & $75.00^{\mathrm{c}}$ & $19.15^{\mathrm{c}}$ & $10.00^{\mathrm{c}}$ \\
\hline 5 & $63.70^{d}$ & $20.04^{b}$ & $13.50^{b}$ & $63.66^{\mathrm{e}}$ & $20.11^{b}$ & $11.80^{b}$ \\
\hline 8 & $60.04^{e}$ & $25.16^{\mathrm{a}}$ & $25.00^{\mathrm{a}}$ & $64.63^{d}$ & $22.04^{\mathrm{a}}$ & $20.00^{\mathrm{a}}$ \\
\hline 10 & $90.04^{b}$ & $17.07^{d}$ & $7.60^{d}$ & $95.32^{b}$ & $14.04^{d}$ & $6.20^{d}$ \\
\hline 12 & $95.04^{\mathrm{a}}$ & $13.04^{\mathrm{e}}$ & $6.00^{\mathrm{e}}$ & $98.22^{a}$ & $8.07^{\mathrm{e}}$ & $5.00^{\mathrm{e}}$ \\
\hline Mean & 76.77 & 18.87 & 12.60 & 80.45 & 16.06 & 10.70 \\
\hline LSD $^{(p=0.05)}$ & 0.52 & 0.28 & 0.32 & 0.73 & 0.25 & 0.29 \\
\hline
\end{tabular}

Similarly in gladiolus inhibition of rooting at higher dose of gamma irradiation had also been reported by (Kumar 2002) in gladiolus.

\section{Radiation on cormel formation}

After two weeks of root initiation (not fully developed roots), the whole cluster of rooted plantlets were taken out from cultures and cultured on cormel induction media
$(1 / 2 \mathrm{MS}+\mathrm{IBA}, 2 \mathrm{mg} / \mathrm{l}+60 \%$ sucrose $)$. New root formation and further development of already existed roots was observed in each explant during the 1st week of culture following development of cormels after 67 weeks. Induction of new shoot primordia was also observed. The effect of gamma rays on days taken to cormel formation, number of cormels and size of cormels showed highly significant differences presented in Table 3. 
The minimum time recorded for cormel formation was in 8 Gy (60.04 days) followed by 5 Gy (63.70 days) which was at par with the control (75.04 days). As the doses of gamma rays were increased the time for cormel development was increased. It was 95.04 days at 12 Gy dose in 'Punjab Glance'. In 'Sylvia' minimum time taken for cormel production was in $8 \mathrm{~Gy}$ (64.63 days) followed by 5 Gy (63.66 days). As the doses of gamma rays were increased the time for cormel development was increased. Maximum days were taken by 12 Gy dose (98.22 days).

In variety 'Punjab Glance' maximum number of cormels (25.16) was recorded at $8 \mathrm{~Gy}$ which was followed by 20.04 at 5 Gy gamma ray dose. Minimum number of cormels (13.04) was observed in higher dose of gamma ray at $12 \mathrm{~Gy}$. Maximum number of cormels (22.04) was recorded at $8 \mathrm{~Gy}$ which was followed by 20.11 at $5 \mathrm{~Gy}$ gamma ray dose. Minimum number of cormels (8.07) was observed in higher dose of gamma ray at 12 Gy in 'Sylvia'. Maximum size of cormels $(25.00 \mathrm{~mm})$ was recorded at 8 Gy which was followed by $13.50 \mathrm{~mm}$ at $5 \mathrm{~Gy}$. Minimum size of $(6.00 \mathrm{~mm})$ cormels was observed in higher dose of gamma ray at $12 \mathrm{~Gy}$ in variety 'Punjab Glance'. In variety 'Sylvia' maximum cormels size $(20.00 \mathrm{~mm})$ was recorded at 8 Gy which was followed by $11.80 \mathrm{~mm}$ at 5 Gy gamma ray dose. Minimum size of cormels $(5.00 \mathrm{~mm})$ was observed in higher dose of gamma ray at $12 \mathrm{~Gy}$. In this experiment it was observed that gamma irradiation of callus from varieties 'Punjab Glance' and 'Sylvia' took around 60 days for cormel formation. As the doses increased to 10 and $12 \mathrm{~Gy}$, the time for cormel formation increased to 95 days. This might be due to harmful effect of gamma rays on bud clumps which inhibits the action of phytohomones synthesised or by the exogenous supply of synthetic auxin. Similar results also reported in rose (Bala and Singh 2013).

\section{Ex-vitro survival and morphological studies}

Field survival of cormels of gladiolus variety 'Punjab Glance' and 'Sylvia' was evaluated after 4 and 8 weeks (Table 4). In this experiment no mortality was observed under untreated callus cultured on MS medium. However, field survival among plants developed from 5 and 12 Gy treatment irradiated shoots was significantly low in $86.33 \%$ and $22.00 \%$ in 'Punjab Glance' and $83.33 \%$ and $20.33 \%$ in 'Sylvia'. The maximum sprouting was recorded under control $(90.00 \%)$ in 'Punjab Glance' and it decreased at higher dose of gamma rays. It was $(22.00 \%)$ at 12 Gy. In 'Sylvia' maximum sprouting i.e. $87.00 \%$ was observed at control and minimum $(20.33 \%)$ was recorded at higher dose $12 \mathrm{~Gy}$. This revealed that higher doses of gamma rays are detrimental for irradiation of gladiolus corms. Survival rate at higher doses might attribute to genetic loss due to chromosomal aberrations and gene mutation. This might be due to the inactivation of auxin content (Gordon 1957). Higher doses may have harmful effects on auxins and other growth substances, chromosome structure and cell division which suppress growth or create lethal effects on cells of the plant resulting in poor survival (Uzenbaev and Nazarenko 1970). These results are in conformity with the results of (Dhaduk 1992) who recorded $\mathrm{LD}_{50}$ for four gladiolus varieties between 7 and $10 \mathrm{Krad}$, when treated with acute gamma irradiation.

Maximum leaf length $(42.33 \mathrm{~cm})$ was observed at $8 \mathrm{~Gy}$ and decreased $16.16 \mathrm{~cm}$ at higher dose at 12 Gy in 'Punjab Glance'. In 'Sylvia' Leaf length $(41.33 \mathrm{~cm})$ was observed maximum at $8 \mathrm{~Gy}$ and decreased $15.66 \mathrm{~cm}$ at higher dose at $12 \mathrm{~Gy}$. Maximum leaf width $(1.83 \mathrm{~cm})$ was observed at $8 \mathrm{~Gy}$ and decreased $0.48 \mathrm{~cm}$ at higher dose at $12 \mathrm{~Gy}$ in 'Punjab Glance'. In 'Sylvia' leaf width (1.68 $\mathrm{cm})$ was observed maximum at $8 \mathrm{~Gy}$ and 
decreased $0.45 \mathrm{~cm}$ at higher dose at $12 \mathrm{~Gy}$. There was greater reduction in leaf length with increasing dosage of gamma rays. This significant reduction might be due to poor growth of plant due to irradiation. Banerji et al., (1994) had also reported reduction in leaf length after irradiation of gladiolus corms with higher doses of gamma rays. Raghava $e t$ al., (1988) also reported reduction in leaf width in gladiolus varieties after 5, 10 and 15 Krad gamma rays treatment. Similarly significant effect of gamma rays on number of cormels (5.93) was found maximum at control. It was decreased (1.00) at higher dose at 12 Gy in 'Punjab Glance'. In 'Sylvia' number of cormels (5.66) was found maximum at control and minimum 1.00 at higher dose 12 Gy. Maximum corm size (2.67 $\mathrm{cm}$ ) was observed at $8 \mathrm{~Gy}$ and minimum 1.00 $\mathrm{cm}$ at 12 Gy in 'Punjab Glance'. In 'Sylvia' maximum corm size $(2.50 \mathrm{~cm})$ was observed at $8 \mathrm{~Gy}$ and minimum $0.96 \mathrm{~cm}$ at $12 \mathrm{~Gy}$. In the present investigation the reduction in number of cormels and size of corm may be attributed to the fact that due to treatment damage, physiology of the plant in higher doses was disturbed which affected photosynthesis and root system resulting in the improper growth of plant. Similar results were found by (Kumari and Kumar 2015) reported that with increase in dose there was significant reduction in the cormels/ plant. At higher doses of gamma rays more production and bigger size of corms were obtained while higher doses resulted in smaller sized corms than control in tuberose (Ali, 2002).

A protocol for in vitro-mutagenesis of gladiolus has been established using gamma rays and may be used in future breeding programmes. The present study revealed that gamma irradiation of nodal explants of gladiolus at 5, 8, 10 or 12 Gy was effective at inducing novel flower colour variants. Induced mutations through tissue culture are desirable for developing new cultivars for the floriculture industry and the cut flower trade to fulfill the demands of both domestic and international markets.

\section{Acknowledgement}

I would like to special thanks to Punjab Agriculture University, Ludhiana for providing university merit fellowship and fruit science department for providing facilities of gamma chamber for conducting my research work.

\section{References}

Ali J (2002) Effect of gamma irradiation on vegetative and floral characteristics of tuberose bulbs (Polianthes tuberosa) $U A F: 90$

Arnold, N. P, Barthakur, N. N and Tanguay, M. 1998. Mutagenic effects of acute gamma irradiation on miniature roses: target theory approach. Hort. Sci. 33: 127-29

Arora, J S, Singh K, Grewal, H S and Chanana, Y R. 1996. In vitro cormel production from nodal buds and cormel tips of gladiolus. In Plant Tissue Culture (Ed. Islam A S), IBH \& Oxford Publishing House Pvt Ltd, New Delhi, India, pp 50-53.

Bala M and Singh K P (2013) In vitro mutagenesis of rose explants using gamma irradiation to induce flower colour mutations. J Hort Sci Biotech 88:462-68.

Banerji, B K and Datta, S K and Sharma, S C. 1994. Gamma irradiation studies on gladiolus cv. 'White Friendship'. $J$. Nucl. Agric. Biol. 23 (3): 127-33.

Dantu, P. K. and Bhojwani, S S. 1995. In vitro corm formation and field evaluation of corm derived plants of gladiolus. Sci. Hort. 61: 115 - 29

Datta, S K, Misra, P and Mandal, A K. 2005 In vitro mutagenesis- a quick method 
for establishment of solid mutant in chrysanthemum. Curr. Sci. 88 (1): 15558

Datta, S. K. and Banerjee, B. K. 1995. Improvement of garden chrysanthemum through induced mutation. Flora and Fauna, 11: 1-4

Dhaduk B K (1992) Induction of mutations in garden gladiolus by gamma rays. Ph.D Thesis, IARI New Delhi.

Duncan D B (1955) Multiple range and multiple F tests. Biometrics 11:1-42.

Gordon, S A. 1957. The effect of ionizing radiation on plants -Biochemical and physiological aspects Quarterly Review of Biology 32: 3-14.

Grewal, H S, Arora, J S and Gosal, S S 1995. Microprogation of gladiolus through in vitro cormlets production. Plant Tiss Cult. 5:27-34

Holdgate, D P. 1977. Propagation of ornamental by tissue culture In: J Reinert and Y P S Bajaj (eds.) applied and fundamental aspects of plant cell, tissue and organ culture. Pp: 18-42

Hussain, I. Muhammad, A. Rashid and Quaishi. 2001 In vitro multiplication of Gladiolus. Plant Tiss Cult 11: 121-26.

Hussey, G 1977. In vitro propagation of gladiolus by precocious axillary shoots formation. Sci Hort 6: 287-96

Jain, S. M. 2005. Major mutation assisted plant breeding programs supported by the FAO and IAEA. Plant Cell, Tissue and Organ Culture, 82: 113-23.

Kapadiya, D. B., Chawla, S. L., Patel, A. I. and Ahlawat, T. R. 2014. Exploitation of variability through mutagenesis in chrysanthemum morifolium var. 'Maghi'. The Bioscan 9:1799-1804.

Kasumi, M., Takatsu, Y., Manabe, T. and Hayashi, M. 2001. The effects of irradiating gladiolus (Gladiolus $\mathrm{x}$ grandiflora Hort.) cormels with gamma rays on callus formation, somatic embryogenesis and flower color variations in the regenerated plants. $J$ Japan Soc Hort Sci 70: 126-28.

Kim, J. H., Baek, M. H., Chung, B. Y., Wi, S. G. and Kim, J. S. 2004 Alterations in the photosynthetic pigments and antioxidant machineries of red pepper seedlings from gamma irradiated seeds. J Plant Bio 47: 314-21.

Kumar S (2002) Studies on in vitro mutagenesis in Rose (Rosa hybrida L) Ph.D thesis submitted to $\mathrm{C} \quad \mathrm{C} \quad \mathrm{S}$ university Meerut.

Kumari, K. and Kumar, S. 2015. Effect of gamma irradiation on vegetative and propagule characters in gladiolus and induction of homeotic mutants. IJAEB 8(2): 413-22.

Kumari, K. Dhatt, K. K. and Kapoor, M. 2013 Induced mutagenesis in chrysanthemum morifolium var. 'Otome Pink' through gamma irradiation. The Bioscan 8:148992.

Logan, A. E. and Zettler, F. W. 1985. Rapid in vitro propagation of virus indexed gladioli. Acta Hort. 164: 169-80

Murashige, T. and Skoog, F 1962. A revised medium for rapid growth and bio-assays with tobacco tissue cultures. Physiologia Plantarum. 15: 473-97.

NHB (2014) Status of floriculture. Directorate of floricultural research. ICAR. New Delhi. Pp:34

Raghava, S. P. S., Negi S S, Sharma, T. V. R. S., and Balakrishnan, K. A. 1988. Gamma ray induced mutants in gladiolus. J Neelam Agric Biol 17: 5-10.

Roy, S.G, Gangopadhyay, T., Bandyopadhyay, B. K., Modak, D., Datta and Mukherjee, K. K. (2006) Enhancement of in vitro microcorm production in gladiolus using alternative matrix. Afri J Biotechno 5: 1204-09.

Singh, A. P. and Dohare, S. R. 1994 Maximization of corms and cormel production in gladiolus. In: Prakash $\mathrm{J}$ and Bhandary K R (Ed.) Flori. Techn. 
Trades and trends, oxford and IBH pub. Co. LTD: 205-08.

Singh, K. P., Singh, B., Raghava, S. P. S., Mishra, R. L. and Kalia, C. S. 1999 In vitro induction of mutation in carnation through gamma irradiation. J Orn Hort 2:107-110.

Singh, P., Misra, S. K., Misra, R. L., and Ranjan, J. K. 2010. In vitro rooting of gladiolus micro shoots. Prog Hort. 42: 243-45

Sinha P and Roy S K 2002 Plant regeration through in vitro cormel formation from callus culture of Gladiolus primulinus. Plant Tiss Cult 12: 139-45.

Sudhir K, Prasad K V and Choudhary M L 2006. Detection of genetic variability among chrysanthemum radiomutants using RAPD markers. Current Science, 90: 1108-13.

Uzenbaev E H and Nazarenko L G (1970) some changes in growth and development of gladiolus under the effect of gamma irradiation from ${ }^{60} \mathrm{Co}$. Trudy Bot Sadov Akad Nauk 11: 26-30.

\section{How to cite this article:}

Neha Dogra and Dhatt, K.K. 2017. In Vitro Production of Cormels in Gladiolus hybridus through Gamma Rays. Int.J.Curr.Microbiol.App.Sci. 6(10): 1308-1318.

doi: https://doi.org/10.20546/ijcmas.2017.610.154 